\title{
APPLICATION OF PROMOTION, MAP AND EXISTING TOURISM INFORMATION SYSTEMS IN SOLOK SELATAN DISTRICT USING ANDROIDJAVA PROGRAMMING LANGUAGE
}

\author{
Hari Marfalino ${ }^{1)}$, Larissa Navia Rani $^{3)}$, Mardison $^{3)}$, Ichsan Pribadi ${ }^{4)}$ \\ Universitas Putra Indonesia "YPTK" Padang

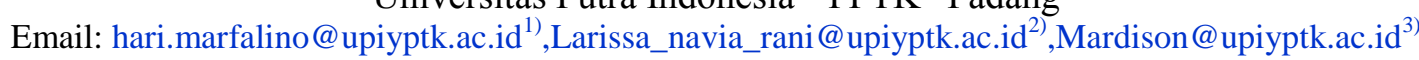 \\ ,Ichsanpribadi01@gmail.com ${ }^{4)}$
}

\begin{abstract}
ABSTRACK
The development of technology and information is felt very rapidly and this affects aspects of work that make work easier, one of which is the development of mobile technology, information media can now be made in the form of mobile applications, using mobile technology in the form of tourist applications, which provide information - information about tourism in the district of Solok Selatan, the search for tourism information in the district of Solok Selatan will be more practical to use and users can use this application wherever they are, this application can be used as a medium of knowledge about tourism in Solok Selatan district. This Solok Selatan tourist application is expected to be able to provide more knowledge about Solok Selatan tourism to the wider community, especially the people of Solok Selatan District.
\end{abstract}

Keywords: Application,Android,tour,Solok Selatan.

\section{INTRODUCTION}

The development of information technology and technology is very rapid and this affects aspects of the work of almost all companies in terms of decision making, information dissemination, increasing the effectiveness of work and promotion using computer information systems (Mardison, 2017). The progress of technology that is developing very rapidly causes the exchange of information to be a necessity. No exception in the field of promotion and marketing, one of the im. Solok Selatan Regency is a district which is located in the eastern part of West Sumatra. The district was officially expanded from Solok District in 2004 and officially became the youngest Regency in West Sumatera, therefore the Regency is still unknown to many people while many beautiful natural resources and culture which is still thick that people should know. Solok Selatan Regency is the youngest regency in West Sumatra Province, the Regency also has a very large area with an area of 3,346.20 km2, with an area of that size certainly not a lot of natural resources that exist in Solok Selatan Regency but it is unfortunate there are still many tourists who are not familiar with this Regency. Therefore, the author wants to promote tourism in Solok Selatan Regency, not only promoting the author, but also helping to provide information and help show the direction of the location with the help of applications that will be designed and map services provided by Google Map. Thus, this application will indirectly attract tourists to visit the Solok Selatan Regency and improve the economy of the community. Android smartphones are used as mobile devices in this study. 
Besides that, there are three technologies used in making this application, namely: (1) global positioning system (GPS), (2) Google maps Android, and (3) Google maps directions. The GPS will provide the coordinates of the location of tourists. While Google maps will display maps on an Android smartphone. Google maps directions will display a visualization of the route from tourist coordinates to the desired tourist destination.

\section{STUDY LITERATURE}

\section{Mobile Application}

In general, applications have many meanings, but technology applications are ready-made programs designed to carry out a function for users and can be used by the intended target, while mobile can be interpreted as moving from one place to another, so Mobile application is a program ready to use to carry out certain tasks installed on mobile devices. (Imam Muttaqin et al., 2017). Systems not only cover an organization but also cover all aspects of life, apart from that the system is very necessary in processing data into an accurate, fast and quality information because the system has interrelated and interconnected procedures to do assignments together. (Mardison, 2015). The steps taken at the stage of designing an information system and the program are making logical problem solving proposals in accordance with existing problems. And the tools used in helping solving problems in making this system include:

\section{Overview of Tourism}

Etymologically the word tourism comes from Sanskrit. "Pari" means many, many times, circling or going around, and "travel" means traveling or traveling. In summary, it can be concluded that tourism is a journey carried out many times from one place to another (Suryadi, 2015).Tourism is all things that correlate with tourism, including the exploitation of tourist objects and attractions as well as businesses related to that field (Imam Muttaqin et al., 2017). According to Law Number 10 of 2009 concerning Tourism in chapter 1 article 1 states that what is meant by tourism is various kinds of tourism activities and supported by various facilities and services provided by the community, entrepreneurs, the Government, and the Regional Government. Tourism is important because it becomes an economic potential that can be utilized by various interested parties (Suryadi, 2015). Tourism is a trip carried out by a person or group of people, which is temporary, to enjoy objects and attractions at the destination. That is, tourism is an activity outside of daily routine activities, such as work or the like. (Suryadi, 2015).

\section{Overview of Google Maps}

Google Maps is a free service provided by Google and very popular. Google Maps is a world map that we can use to see an area. In other words, Google Maps is a map that can be seen using a browser (Rismayani, 2016). Android Studio is Integrated Development Environment (IDEGoogle's 
main) to develop on the Android platform. Because Android Studio is an IDE from Google, this software can be directly integrated with Google Maps using the API Key created on the page provided from the Google Maps API to integrate maps with software so that the map will automatically be displayed in the application made (AnisaRachmawati, et al, 2017). Apart from being integrated with Google Maps, Android Studio can also be integrated with the SQLite Manager database, plugins for processing and storing information that are interrelated for later algorithms made from each data that will be displayed. (Anisa Rachmawati, et al., 2017)

\section{Android SDK (Software Development Kit)}

Android SDK is an API (Application Programming Interface) tool that is needed to start developing applications on the Android platform using the Java programming language. (HarniKusiyanti, et al, 2016). Android SDK includes a comprehensive set of development tools. The Android SDK consists of debuggers, libraries, emulator handsets, documentation, program code samples and tutorials. (SulihatiAdrayani, 2016). Some important Android features are as follows: (Harni Kusiyanti, et al, 2016)

Application framework that supports component replacement and is reusable. DVM is optimized for mobile devices. Integrated browser based on the WebKit open source engine. Graphics are optimized and supported by 2D graphics libraries, 3D graphics based on the OpenGL ES 1.0 specification. SQLite for data storage. Support for audio, video and images. Bluetooth, Edge, 3G, Wifi. Camera, GPS, compass and accelerometer

\section{Android \\ Definition of Android}

Android is a Linux-based operating system designed for touch screen mobile devices such as smartphones and tablet computers. Android was originally developed by Android, Inc. with Google financial support, which later bought it in 2005. (HarniKusiyanti, et al., 2016). Android is an operating system application for cellphones based on Linux. Android provides anplatform openfor developers to create their own applications for use by various mobile devices. (Sulihati Adrayani, 2016).

\section{Research Methods}

This framework is the steps that will be taken in solving the problem to be discussed. In this sub-chapter the research framework will be described based on the picture above:

\section{Data Collection}

This frameworkwork starts from data collection, which consists of library and laboratory research.

\section{a. LibraryResearch)}

This research is done to complement the treasury rules, concepts, theories and others, so that becomes a basis and scientific steady, in addition, this study also conducted research on materials that already exist, whether it's a book books, journals, magazines that have to do with this research. This study is intended to collect all the data that is needed in this study.

\section{b. LaboratoryResearch}


Laboratory Research is intended for laboratory research are undertaking testing of the application of expert system using a rule-based system withtechnique, forward chaining especially to problems detected viral illness in children. In this laboratory research can not be separated from the device or device used, where the devices used in this study are:

\section{Data Analysis}

After collecting the data above, an analysis of the data is carried out. This aims to group the data so that the author will make it easier to do the next analysis. In accordance with the title of this research that uses Android and UML as a tool to build applications and systems, analysts need to use the data to be used, so that analysis can be done.

\section{System Analysis}

After data analysis is done, the next research framework is system analysis. In this analysis, it is expected to produce problem analysis, including:

\section{Designing Model}

This stage discusses the design of the system by determining the design of inputs, outputs and objects that will be used in determining tourist objects. In designing this system the things that are done are:

\section{Design of the Model}

Model is an illustration of the solution that will be produced, so that from the existing model, we can find out and describe what will be produced from the process carried out later. Thus we have guidelines in designing systems.

\section{b. Input Design}

Based on the techniques used above, input design can be done from this system, thus the next process can be done based on the design of the input.

\section{c. Designing objects}

Based on the design of the model and the design of inputs, the next step will be the design of the mapping of attractions that will be used in the design of the android application. With the mapping of this route can help to make a decision.

\section{System Development}

This stage discusses the development of an Android-based tourism system in southern Solok in the form of an Androidbased application, which includes data input, output and mapping of tourist routesto determine the tourist location of Solok Selatan.

\section{System Testing}

At this stage of testing the system to test the system, look for any errors or errors that are still in the system, then to be able to be repaired so that it can assist researchers in determining the route of attraction on the south side.

\section{System Implementation}

The next step that will be carried out in the research is implementing the designed system. In the implementation of this system the author uses an android-based application that has been designed to determine the tourist route on the south side

\section{System Evaluation}

System evaluation is a stage to see the reliability of a system, whether the system is made with the route that matches the desires and the extent to which the system is applied. The results obtained will be evaluated whether the problems faced so far can be resolved properly. 


\section{Implementation and System Testing}

\section{System Implementation}

System implementation is a system that is ready to use to be applied to a company that has been studied. Before being implemented directly on the company, it is necessary to test first whether the system is running correctly and also a direct test of how to run the system for the user.

\section{Requirement and Installation System}

Before implementing and running applications solsel travel, the required specification(hardware) and

software(software), as well as the steps that must be done to be able to run this application in order to function properly.

\section{Hardware Requirements}

To be able to run the system that is made this requires hardware and software with certain specifications. To run this application as a client, you need an Android smartphone with the minimum specifications as follows:

- Display: 320 x 480 pixels 3.2 "

- $\quad$ CPU: Cortex A8 $1 \mathrm{GHz}$

\section{Software Requirements}

Software is a non-physical component used to make computer systems run and do his duty. The software needed and tested on client computers is:

1. OS: Android version 6.0 (Marshmallow)

2. Solok Selatan tourism application

\section{Installation Program}

To run the Solsel tourist application on the smarth phone android client, there are several installation stages that need to be implemented to avoid interruption during installation application, the following steps in the installation of a tourist application solsel

\section{Enable Licensing Application Sources unknown}

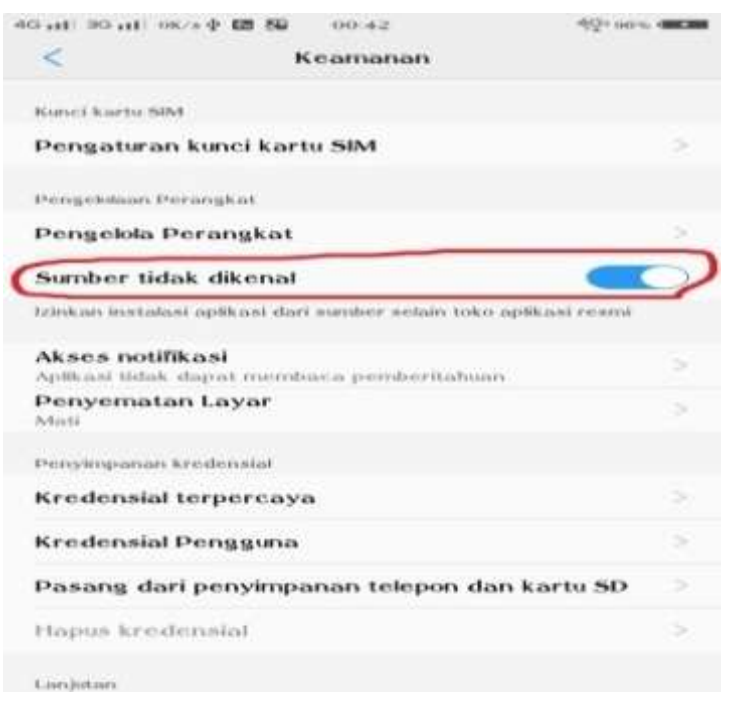

Figure 1. Install the Solok Selatan Tourism
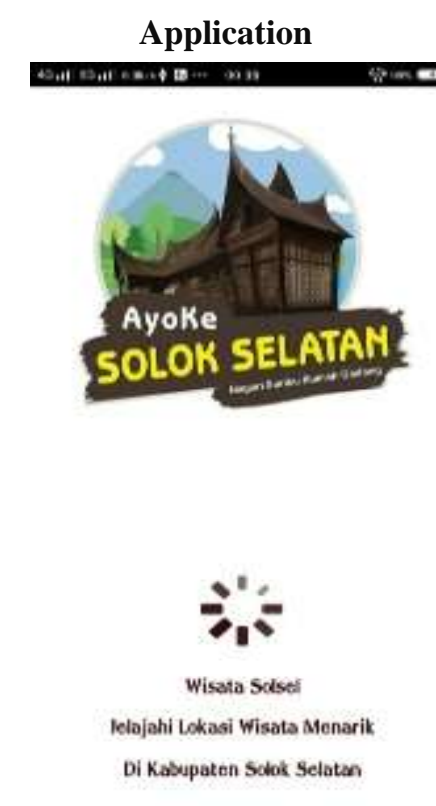

Figure 2. Splash Screen Display

\section{Start Page Display}




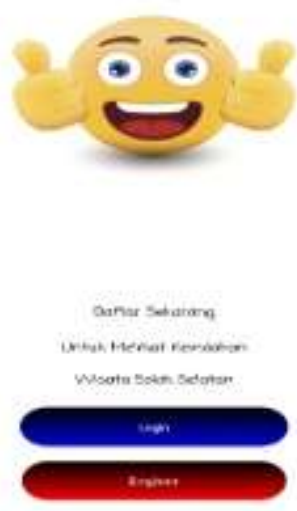

Figure 3 Start Page

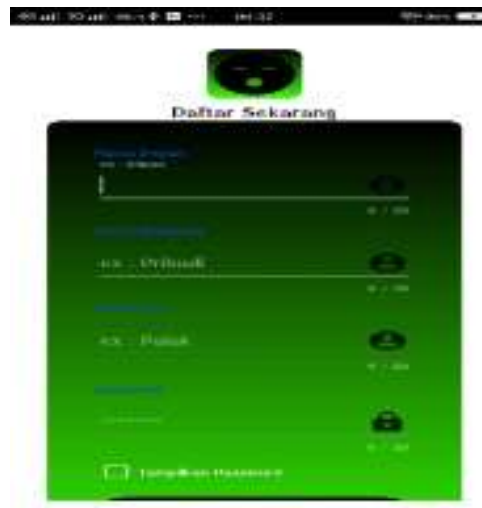

Figure 4. Registration Page

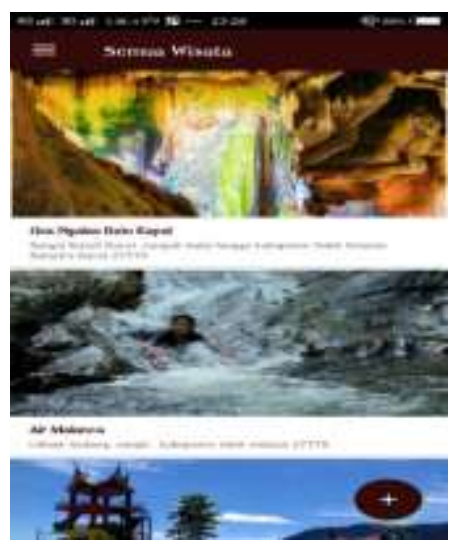

Figure 5. Main Menu Page

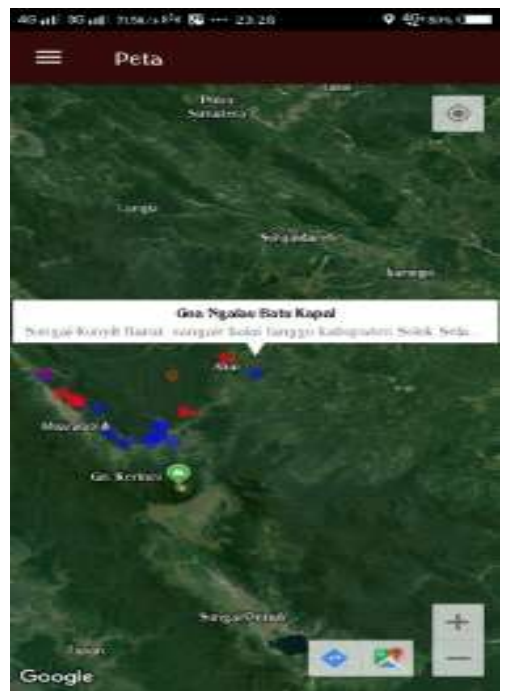

Figure 6. Tourist Map Page

\section{Conclusions}

\section{Conclusions}

Based on the research that the author has done on, it can be concluded as follows:

1. With the existence of this Solok Selatan tourism application, it can help tourism agencies in promoting tourism in Solok Selatan Regency.

2. With this application, it is not yet clear the addition of tourists visiting Solok Selatan Regency due to the large number of people who still do not know this application and the little research time

3. This application can facilitate users in finding tourist information and tourist locations along with fast routes to tourist sites. in

\section{REFERENCES}

[1] Palevi.,A.,R, Krisnawati. (2013). Analisis Dan Perancangan Sistem Informasi Penerimaan Peserta Didik Baru Berbasis Website Pada Smp 
Negeri 2 Mojosongo Boyolali. JurnalIImiah DASI, 14, 1 - 6

[2] RachmawatiAnisa, dkk. (2017). Desain Aplikasi Mobile Informasi PemetaanJ alur Batik Solo Trans Berbasis Android Menggunakan Location Based Service. Jurnal Geodesi Undip , 6

[3] Fridayanthie., E.,W , Mahdiati Tias. (2016). Rancang Bangun Sistem Informasi Permintaan Atk Berbasis Intranet (Studi Kasus: Kejaksaan Negeri Rangkasbitung). Jurnal Khatulistiwa Informatika, 4

[4] MahdiaFarya, NoviyantoFiftrin. (2013). Pemanfaatan Google Maps ApiUntuk Pembangunan Sistem Informasi Manajemen Bantuan Logistik Pasca Bencana Alam Berbasis Mobile Web ( StudiKasus : Badan Penanggulangan Bencana Daerah Kota Yogyakarta ). Jurnal Sarjana Teknik Informatika, 1

[5] Ardy Ferly. (2016). Sistem Informasi Pengisian Nilai Berbasis Java Web Menggunakan Local Server PadaSmk 2 Mei Bandar Lampung. JurnalCendika , 12

[6] KusniyatiHarni, Sitanggang.,N.,S.,P. (2016). Aplikasi Edukasi Budaya Toba Samosir Berbasis Android. Jurnal Teknik Informatika , 9

[7] Muttaqin Imam, dkk . (2017). Jurnal Ilmiah Rekayasa dan Manajemen Sistem Informasi ,Jurnal Ilmiah Rekayasa dan Manajemen Sistem Informasi , 3 .

[8] Mardison . (2015). Perancangan Dan Implementasi E-Commerce Pada Rumah Songket Pusako Minang
Pandai Sikek ,Jurnal KomTekInfo Fakultas IlmuKomputer, 2.

[9] Mardison (2017). PerancanganSistemInformasi Inventory PadaAlinia Mart Berbasis Multi User Dengan Java Netbeans Dan Mysql , MajalahIlmiah, 24, 221 230.

[10]BarriMaria.W.H ,Dkk . (2015). PerancanganAplikasiSms Gateway Untuk Pembuatan Kartu Perpustakaan di Fakultas Teknik Unsrat, E-journal Teknik Elektro dan Komputer.

[11] Asmara Rini. (2016). Sistem Informasi Pengolahan Data Penanggulangan Bencana Pada Kantor Badan Penanggulangan Bencana Daerah (Bpbd) Kabupaten Padang Pariaman, Jurnal J-Click, 3.

[12]Rismayani. (2016). Pemanfaatan Teknologi Goole Maps Api Untuk Aplikasi Laporan Kriminal Berbasis Android Pada Polrestabes Makassar, Jurnal Penelitian Pos dan Informatika 6, 185-200.

[13]Hermawan Rudi, Dkk. (2016). Sistem Informasi Penjadwalan Kegiatan Belajar Mengajar Berbasis Web (StudiKasus :YayasanGanesha Operation Semarang), Indonesian Journal on Software Engineering 2 , 31-38.

[14] SophianSophan.

(2014). Pengimplementasian Dan Perancangan Sistem InformasiP enjualan Dan Pengendalian Stok Barang Pad aToko Swastika Servis (Ss) Bangunan Dengan Menggunakan Bahasa Pemrograman Visual Basic 6.0 Didukung Dengan Database Mysql, Jurnal Momentum 16, 34-44. 
[15] AndriyaniSulihati. (2016). Aplikasi Akademik Online Berbasis Mobile Android Pada Universitas Tama Jagakarsa, Jurnal Sains Dan Teknologi11 , 1-66.

[16] Suryadi. (2015). Aplikasi Akademik Online Berbasis Mobile Android Pada Universitas Tama Jagakarsa, Jurnal Utilitas 1 , 157-197.

[17]Putra.,Y.,A , Sumijan, Mardison. (2018). Perancangan Sistem Informasi Akademik Menggunakan Bahasa Pemograman Php Dan Database Mysql (Studi Kasus Paud Terpadu Bissmillah Kota Bukittinggi), Jurnal Teknologi, 8 , 26-33.

[18] Tata Sutabri, 2012.Komponen Sistem Informasi. yogyakarta 